\section{Algal biomass unaltered by food-web changes in Lake Michigan}

\section{John T. Lehman}

Department of Biology and Great Lakes Research Division, Natural Science Building, The University of Michigan, Ann Arbor, Michigan 48109, USA

Bythotrephes cederstroemii Schoedler (Crustacea: Cladocera), a predator previously confined to the Palearctic, has successfully invaded the North American Great Lakes ${ }^{1-3}$. Bythotrephes is a voracious predator on herbivorous Cladocera, including the dominant grazers in Lake Michigan during the summer. Lake Michigan has been the source of active debate regarding the relative importance of nutrient income versus food-web relations to its trophic state and water quality ${ }^{4-6}$. The recent species invasion has directly altered the lake's food web at a middle trophic level. During summer 1987 Bythotrephes populations increased rapidly in the offshore regions of Lake Michigan and abundances of herbivorous zooplankton simultaneously declined. Despite the resulting relaxation of herbivory, particulate chlorophyll concentrations, an index of algal biomass, did not increase. These results suggest that primary producers are most constrained by abiotic forces in this deep oligotrophic lake.

The arrival of Bythotrephes in North America ${ }^{1-3}$ has caused a novel perturbation of existing plankton communities. The rising abundances of Bythotrephes at an offshore reference station at $43^{\circ} \mathrm{N} 86^{\circ} 40^{\prime} \mathrm{W}$ (36-km offshore; depth, $100 \mathrm{~m}$ ) in Lake Michigan were associated with pronounced changes in the abundances of other zooplankton taxa. Zooplankton abundances on 30 June 1987, when Bythotrephes was rare, in most cases equalled or exceeded abundances recorded during 1985 and 1986 before the arrival of the predator (Table 1). Epilimnion temperatures were warmer in 1987 than in the previous two years, and the warm water promoted the early success of most crustacean taxa other than Limnocalanus and Senecella, which are hypolimnion-dwelling cold stenothermic copepods ${ }^{7}$. By 22 July 1987 Bythotrephes had increased to more than 200 individuals $\mathrm{m}^{-2}$, and the abundances of five other plankton species were significantly different from levels recorded in 1985 and 1986 (Table 1).
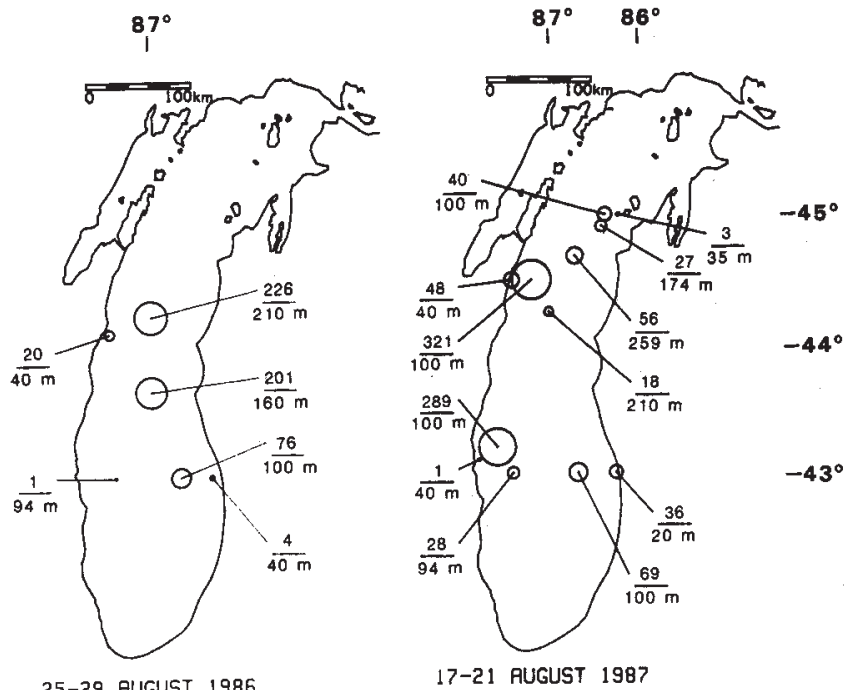

Fig. 1 Abundances (individuals $\mathrm{m}^{-2}$ ) of Bythotrephes in Lake Michigan during survey cruises in August 1986 and 1987. Areas of the plotted circles are proportional to abundances. Numerators, individuals $\mathrm{m}^{-2}$ in water column from surface to within $5 \mathrm{~m}$ of bottom; denominators, depth of water column.
The depth-integrated plankton abundances reported in Table 1 have only a $20 \%$ estimation error ${ }^{8}$. By first-order error propagation $^{9}$, abundance ratios between years are subject to standard errors of estimation equal to $28 \%$ of the ratio. Ratios are thus not regarded to be significantly different from 1.0 at the 0.05 probability level $(1.0 \pm 2$ s.e.m.) unless they are less than 0.44 or greater than 2.27 (the reciprocal of 0.44). All three Daphnia species (D. pulicaria, D. galeata mendotae and D. retrocurva), as well as Leptodora kindtii, declined in July 1987 and subsequently remained low during sampling cruises in August and September. The only crustacean to increase substantially, other than Bythotrephes itself, was Epischura lacustris. Epischura is univoltine and its population growth was due to accelerated recruitment of copepodids from naupliar stages earlier than usual because of warm temperatures. Epischura is carnivorous only in its late copepodid stages, and although capable of consuming Daphnia occasionally, it preys principally on zooplankton much smaller than Daphnia ${ }^{10}$.

The spatial distribution of Bythotrephes during late August 1986 was consistent with a presumed invasion route from Lake Huron in the north (Fig. 1). By 1987, Bythotrephes was no longer in an early colonizing phase, but populations nonetheless developed asynchronously in different regions of the lake. In August 1987, Bythotrephes was in greatest abundance at deep $(100 \mathrm{~m})$ stations in western Lake Michigan. Populations on the east side of the lake had declined from similar high abundances one month earlier (Table 2).

Generation times for parthenogenically reproducing Bythotrephes are less than two weeks ${ }^{11}$. Females are iteroparous, and clutch sizes averaged 4.4 embryos per female in 1987 . With

Table 1 Abundances of dominant crustacean zooplankton at an offishore reference station in Lake Michigan $\left(43^{\circ} \mathrm{N} 86^{\circ} 40^{\prime} \mathrm{W}\right)$ during comparable cruise periods in $1985-87$

$\begin{array}{cc}\text { Individuals } \mathrm{m}^{-2} \\ 1985 & 1986\end{array}$

\section{Taxon}

Diaptomus spp. C1-C

Cyclops spp. $\mathrm{C1}-\mathrm{C} 6$

Daphnia galeata mendotae

Daphnia pulicaria

Daphnia retrocurva

Bosmina longirostris

Limnocalanus macrurus

C1-C6

Senecella calanoides

C1-C6

Epischura lacustris

C1-C6

Leptodora kindtii

Bythotrephes

cederstroemii

Temperature at $5 \mathrm{~m}\left({ }^{\circ} \mathrm{C}\right)$

Diaptomus spp. C1-C6
Cyclops spp. C1-C6
Daphnia galeata
mendotae
Daphnia pulicaria
Daphnia retrocurva
Bosmina longirostris
Limnocalanus macrurus
C1-C6
Senecella calanoides
C1-C6
Epischura lacustris
C1-C6
Leptodora kindtii
Bythotrephes
cederstroemii
Temperature at $5 \mathrm{~m}\left({ }^{\circ} \mathrm{C}\right)$

(25-26 June
472,600
290,100
17,800
34
32,400
30,800
14,600
45
110
16

11.5

16-18 July

$$
\begin{array}{r}
383,800 \\
316,300 \\
28,040 \\
\\
18,800 \\
15,740 \\
23,090 \\
9,550 \\
456 \\
522 \\
2,677 \\
0
\end{array}
$$$$
456
$$

18.6
1987

Ratios

$\underline{1987 \quad 1987}$

(7-8.July)

$\begin{array}{rr}663,700 & 832,200 \\ 423,700 & 719,000 \\ 84,280 & 97,460\end{array}$

19851986

$\begin{array}{ll}1.76 & 1.25\end{array}$

$2.48 \quad 1.70$

$5.48 \quad 1.16$

3,473

56,480

70,360

7,480

2,300

2,300
46,170
18,540

$6.67 \quad 0.66$

$\begin{array}{ll}6.67 & 0.66 \\ 1.42 & 0.82\end{array}$

$\begin{array}{lll}8,540 & 0.60 & 0.26\end{array}$

$\begin{array}{lll}7,210 & 0.49 & 0.96\end{array}$

380

318

$0.70 \quad 0.84$

64

738

$6.7111 .53^{*}$

1,975
0

1,388

$8.21 \quad 0.70$

14.9

18.0

22-23 July 22 July

705,100

408,400

67,360

646,400 404,000

2,260

$1.68 \quad 0.92$

$\begin{array}{ll}1.28 & 0.99\end{array}$

17,440

18,380

39,300

9,260

345

$\begin{array}{lll}345 & 0.02 \quad 0.02\end{array}$

$\begin{array}{lll}26,610 & 1.15 & 0.68\end{array}$

$15,520 \quad 1.62 \quad 1.68$

292

512

$1.12 \quad 1.75$

340

3,842

$7.3211 .30^{*}$

2,892

0

$0.00 \quad 0.00 *$
Only copepodid stages (C1-C6) are tabulated for copepods. Abundances sig nificantly different in 1987 from both previous years are denoted by an asterisk. 
Table 2 Reproductive condition of adult female Bythotrephes collected from offshore Lake Michigan in 1987

\begin{tabular}{|c|c|c|c|c|}
\hline & June & July & August & September \\
\hline Fecund parthenogenic females & 60 & 368 & 15 & 71 \\
\hline Barren females & 10 & 200 & 8 & 31 \\
\hline $\begin{array}{l}\text { Gametogenic females with } \\
\text { resting eggs }\end{array}$ & 0 & 72 & 12 & 31 \\
\hline Bythotrephes $\mathrm{m}^{-2}$ & 11 & 239 & 69 & 164 \\
\hline \multicolumn{5}{|l|}{ Abundance ratios } \\
\hline Daphnia: Bythotrephes & 13,270 & 11 & 318 & 380 \\
\hline
\end{tabular}

Frequency distributions change significantly through time (overall $\chi^{2}=52.8$, 6 d.f.; $P=1.3 \times 10^{-9}$ ). There were proportionally more barren and gametogenic females in July than in June, and proportionally more gametogenic females in August than in July. Reproductive conditions of females in August and September were statistically indistinguishable.

its short generation time, Bythotrephes can quickly dominate the dynamics of prey populations, but its influence may subside equally rapidly. The collapse of the Daphnia population in Lago Maggiore, for instance, has been attributed to predation from Leptodora and Bythotrephes ${ }^{12-14}$. Short-lived predators like Bythotrephes, however, may become victims of their own success. By mid-July 1987, the ratio of Daphnia to Bythotrephes had dropped to less than 30 to 1 at the offshore reference station (Table 2). The subsequent decline in Bythotrephes in August was associated with production of resting eggs, rather than parthenogenic eggs, an indication of food limitation. The proportions of barren Bythotrephes females and those bearing resting eggs increased significantly from June to July, when the Daphnia populations declined (Table 2). Daphnia species, in contrast, remained parthenogenic and fecund during their decline. Cladocera switch from parthenogenic reproduction to gametogenic production of resting eggs when food levels fall precipitously ${ }^{15}$.

Leptodora, another predatory cladoceran, was virtually absent by July 1987 during the peak population development of Bythotrephes. Bythotrephes co-exists with Leptodora in European lakes $^{16}$, and so the loss of Leptodora in Lake Michigan was an unusual development. The two predators forage in different ways, but they both take small Cladocera as prey. Bythotrephes is the stronger swimmer and it possesses a stout $(\sim 1 \mathrm{~cm})$ abdominal spine with up to three recurved barbs ${ }^{17}$. Leptodora is an almost transparent, soft-bodied animal with no sclerotized structures besides its mandibles. In June, Bythotrephes were found with remains of Leptodora trailing from their spines. Thus some incidental direct mortality may have caused the decline of Leptodora.

Nutrient income to Lake Michigan and per capita loading of phosphate by human activities have been restricted for more than a decade, in an effort to maintain the oligotrophic condition of the lake ${ }^{18}$. Owing to the century-long hydraulic residence time of the basin the responses have been relatively gradual, but evidence is accumulating that the measures are having success ${ }^{4}$. Lake Michigan has also been stocked with piscivorous salmon for two decades. Resulting changes in abundances of forage fish, primarily the planktivorous alewife (Alosa pseudoharengus) have been expected to cause changes that rival the effects of nutrient reduction. In Lake Michigan this dichotomy of management themes has initiated debate about the strength of nutrient controls and fishery management on trophic state and water quality ${ }^{4-6}$. Now, however, the lake ecosystem has endured a rapid manipulation at a middle trophic level by direct species invasion. Coincidentally, the invasion has provided evidence to refute the hypothesis that trophic interactions control the total biomass of algae in Lake Michigan. Daphnia are biomass dominants and the major epilimnetic herbivores during summer in Lake Michigan ${ }^{8}$, and alterations in their abundance have been linked to changes in algal concentrations in other lakes ${ }^{19}$. Figure 2 shows the mean concentrations of chlorophyll $a$ from surface to $20 \mathrm{~m}$ at the reference

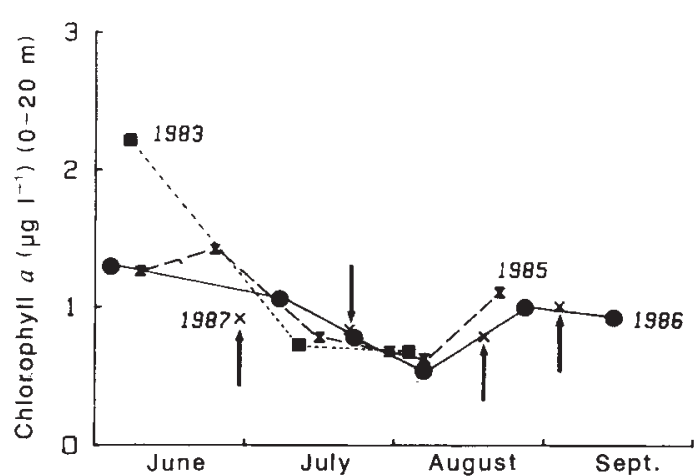

Fig. 2 Mean concentrations of chlorophyll $a$ from surface to $20 \mathrm{~m}$ at the offshore reference station at Lake Michigan. Values in 1987 are indicated by arrows.

station in 1985,1986 and 1987 , as well as chlorophyll $a$ measured at nearby stations in 1983 (ref. 14). During July and August 1987, when Daphnia populations were at 10-50-fold lower abundance than in previous years, the biomass of algae measured as chlorophyll $a$ was unchanged from previous values. Evidentally, the maximum biomass of algae in Lake Michigan is constrained by forces other than herbivory.

I thank J. Bowers, D. Burdette and the crew of the RV Laurentian for assistance with field sampling. This work was supported by the NSF.

Received 14 December 1987; accepted 25 February 1988.

. Lehman, J. T. Oecologia 74, 478-480 (1987)

. Lange, C. \& Cap, R. J. Great Lakes Res. 12, 142-143 (1986)

3. Bur, M. T., Klarer, D. M. \& Krieger, K. A. J. Great Lakes Res. 12, 144-146 (1986)

Scavia, D., Fahnenstiel, G. L., Evans, M. S., Jude, D. J, \& Lehman, J. T. Can. J. Fish. aquat Sci. 43, 435-443 (1986).

5. Edgington, D. in The Future of Great Lakes Resources 24-33 (University of Wisconsin Sea Grant Institute Madison, 1984).

6. Schelske, C. L., Stoermer, E. F., Conley, D. J., Robbins, J. A. \& Glover, R. M. Science 222, 320-322 (1983)

. Balcer, M. D., Korda, N. L. \& Dodson, S. I. Zooplankton of the Great Lakes (University of Wisconsin Press, Madison, 1984).

8. Dorazio, R. M., Bowers, J. A. \& Lehman, J. T. J. Plankton Res. 9, 891-899 (1987).

9. Meyer, S. L. Data Analysis for Scientists and Engineers (Wiley, New York, 1975).

10. Kerfoot, W. C. Limnol Oceanogr 22, 316-325 (1977).

1. Mordukhai-Boltovskaya, E. D. Doklady Akad. Nauk SSSR 112, 1133-1135 (1957)

12. Argentesi, F., de Bernardi, R. \& Di Cola, G. Mem. Ist. Ital. Idrobiol. 31, 245-275 (1974).

13. de Bernardi, R. Mem. Ist. Ital. Idrobiol. 31, 221-243 (1974).

4. de Bernardi, R. \& Canali, S. Mem. Ist. Ital. Idrobiol. 32, 365-392 (1975).

5. d'Abramo, L. Limnol. Oceanogr. 25, 422-429 (1980).

6. de Bernardi, R., Giussani, G. \& Manca, M. Hydrobiologia 145, 225-243 (1987)

7. Ischreyt, G. Int. Rev. Ges. Hydrobiol, 31, 181-202 (1934).

18. Slater, R. W. \& Bangay, G. E. in Phosphorus Management Strategies for Lakes (eds Loehr, R. C Martin C. S \& Rast, W) 13-26 (Ann Aroor Science, 1980)

19. Edmondson, W. T. \& Litt, A. H. Limnol Oceanogr 27, 272-293 (1982)

Rapid changes in genetic structure of epidemic populations of Ophiostoma ulmi

\section{M. Brasier}

Forest Research Station, Alice Holt Lodge, Farnham, Surrey GU10 4LH, UK

The Northern Hemisphere is currently experiencing simultaneous epidemics of Dutch elm disease, caused by two new and highly pathogenic forms of Ophiostoma (Ceratocystis) ulmi, termed the Eurasian (EAN) and North American (NAN) races of the aggressive subgroup. The NAN aggressive has spread across North America $^{1,2}$ and into western Europe, probably through Britain ${ }^{3,4}$; the EAN has migrated westwards across Europe, and into southwestern and central Asia,5. They are now replacing the 'old' non-aggressive subgroup believed to be responsible for the first milder epidemic of the disease during the 1920s to 1940s (refs 5-9), and most mature elms are likely to be killed in affected areas $^{5}$. This situation has provided an opportunity to examine 